\title{
Building the framework of local Adiwiyata schools in Sintang District, West Kalimantan Province
}

\author{
Hendra Setiawan ${ }^{\mathrm{a}, 1^{*}}$, Rachmi Afriani ${ }^{\mathrm{a}, 2}$, Maria Delfiana Dhae ${ }^{\mathrm{a}, 3}$ \\ a Departement of Biology Education, Faculty of Teaching Trainning and Education, Universitas Kapuas Sintang, \\ JI. Y.C. Oevang Oeray No. 92, West Kalimantan, 78612, Indonesia \\ ${ }^{1}$ hendra_setiawan09@yahoo.com *, ${ }^{2}$ rachmiafriani@yahoo.com, ${ }^{3}$ delfinadhae@gmail.com \\ ${ }^{*}$ Corresponding author
}

\begin{tabular}{|c|c|}
\hline ARTICLE INFO & ABSTRACT \\
\hline \multirow[t]{2}{*}{$\begin{array}{l}\text { Article history } \\
\text { Received June 29, 2019 } \\
\text { Revised October 30, } 2019 \\
\text { Accepted November 19, } 2019 \\
\text { Published November 30, } 2019 \\
\\
\text { Keywords } \\
\text { Adiwiyata school } \\
\text { Framework and local plants } \\
\text { Sintang tradition }\end{array}$} & $\begin{array}{l}\text { The suitable framework will enable schools to perform Adiwiyata in the best way based } \\
\text { on their local potentials. The aim of this research was to get better knowledge about the } \\
\text { conditions of schools awarded Adiwiyata as well as to analyze the specific strategies to } \\
\text { create sustainable development of those Adiwiyata schools in Sintang district. This } \\
\text { qualitative descriptive research used purposive sampling technique in which the } \\
\text { participants were SDN } 7 \text { Sintang, SMPN } 3 \text { Sungai Tebelian, and MTsN Sintang. The } \\
\text { data was collected through questionnaire, in-depth interview, and field observation. The } \\
\text { data gained were analized using SWOT. The results indicated that the all Adiwiyata } \\
\text { schools achieved outstanding scores ( } 73.15 \text { for SDN } 7 \text { Sintang, } 70.40 \text { for SMPN } 3 \\
\text { Sungai Tebelian, and } 68.13 \text { forMTsN Sintang). Based on the SWOT analysis, the } \\
\text { specific strategies to develop Adiwiyata schools in Sintang district were by utilizing of } \\
\text { local unique including planting local plants, developing local culture and tradition on } \\
\text { mutual collaboration with surrounding community, and increasing partnership with } \\
\text { environmental agencies and the other third parties in building human resources } \\
\text { who were reliable in maintaining environmental school program. }\end{array}$ \\
\hline & $\begin{array}{r}\text { Copyright } \odot \text { 2019, Setiawan et al } \\
\text { This is an open access article under the CC-BY-SA license }\end{array}$ \\
\hline $\begin{array}{l}\text { How to cite: Setiawan, H., } \\
\text { West Kalimant } \\
\text { jpbi.v5i3.8761 }\end{array}$ & $\begin{array}{l}\text { \& Dhae, M. D. (2019). Building the framework of local Adiwiyata schools in Sintang Distri } \\
\text { e. JPBI (Jurnal Pendidikan Biologi Indonesia), 5(3), 471-480. doi: https://doi.org/10.222 }\end{array}$ \\
\hline
\end{tabular}

\section{INTRODUCTION}

A good school need to establish a positive climate for learning including facilities and environment, It may lead to the greater learning process (Goldstein \& Brooks, 2013). Clean and comfortable school environment may result the optimal learning process (Caddafie, Kariada, Martuti, Rudyatmi, \& Article, 2017; Horta et al., 2017; Morton, Atkin, Corder, Suhrcke, \& van Sluijs, 2016). Maintenance of school environment is the responsibility of all members in the all citizens of the school (included the principal, teachers, staff, students and all parties' affects and affected by school). Indonesia Education stakeholders also need to undertake the activities. 
The Adiwiyata program from the Ministry of Environment and the Ministry of Education (also with the Ministry of Religion) is designed to promote a comfortable and ideal environment to improve knowledge, skills, ethics, and social norms in society (Pradini, Sudjanto, \& Nurjannah, 2019). Adiwiyata is a popular term in Indonesia to refer to the green school program (Husin \& Saleh, 2019; Rachman \& Maryani, 2018; Trihantoyo \& Rahma, 2018; Warju, Ariyanto, \& Muzaki, 2018). Schools can be categorized as Adiwiyata Schools, if they have four main components; Environment-based regulations, implementation of environment-based curriculum, participatory environment-based activities, and facility management to support environmental behavior (Nurwidodo et al., 2019), however, not all schools that propose the Adiwiyata program have fulfilled it.

The carrying capacity of the Adiwiyata school program as an effort to create a caring school environment by the school community that has not been maximized can have an impact on the lack of awareness and proenvironment behavior. Sensitivity to the environment is a basic attitude to realize pro-environment behavior in all school residents (De Dominicis, Schultz, \& Bonaiuto, 2017; Nurwidodo et al., 2019). Based on Estrada, Schultz, Silva-Send, \& Boudrias (2017) pro-environmental behavior can arise in the community which share the same vision and interest. The citizens of the school who desire to maintain school environment are expected to be pioneer in creating clean and comfortable environment, and promote the pro-environmental behavior in the bigger scale, especially in their community. People with pro-environmental behavior generate the basic fundamentals to anticipate the global environmental issues which growth recently (Sloot, Kutlaca, Medugorac, \& Carman, 2018).

Environmental protection and restoration are the major challenges faced by our society, however, very few studies conducted focused in understanding the environmental behavior of its citizens (Bronfman, Cisternas, López-Vázquez, De la Maza, \& Oyanedel, 2015). On this day, the problem is that many of national policy cannot be implemented well because it not crosses the localities of that area. Adiwiyata school program has been existing in Sintang District, West Kalimantan Province since 2011. This program is coordinated by Environmental Agencies in Sintang District. The number of Adiwiyata schools in Sintang district today were 34 schools consisting of four senior high schools (Sekolah Menengah Atas/SMA/SMKMA), eight junior high schools (Sekolah menengah Pertama/SMP/MTs) and 18 elementary schools (Sekolah Dasar/SD/MI). These numbers are not significant compared to the total number of schools in Sintang District. The numbers of elementary schools (Sekolah Dasar/SD/MI) in this area are more than 450 schools. It is expected that the program will grow in all sub-districts to represent the local unique in Sintang.

Adiwiyata program who build driving force that develop pro-environmental behavior is in line with the government of Sintang district program. The Sintang regent, dr. Jarot Winarno, M.Med.PH declared that Sintang will be a "sustainable district", a program initiated by the forum named Lingkar Temu Kabupaten Lestari (LTKL). It's also declare in Sintang Regent Regulation Number 66 Year of 2019 about "District Action Plan of Sustainable Sintang". The aim of this regulation is to build the economics sectors with the sustainable development strategies and promote pro-environmental behavior to all inhabitants. Based on Sintang government program above, the development of human resouces who have pro-environmental behavior is important and Adiwiyata program can be one of the solutions to build the driving force.

The aim of this research was to get better knowledge about the condition of school awarded as Adiwiyata school as well as to analyze the specific strategies in order to develop Aidiwiyata school in Sintang district. The importance of this research is that it can have implications for the development of the Adiwiyata school, especially in strengthening pro-environmental behavior in students. The suitable framework will enable schools to perform Adiwiyata in the best way based on their local potentials. Various efforts to develop effective strategies in organizing Adiwiyata or green school programs are very important to continue, which in turn can encourage students and all parties to be involved in this program. It is expected that the information to formulate the fittest strategies to gain the human resources who have pro-environmental behavior.

\section{METHOD}

This research was conducted on February-May 2019 in Sintang District. This research is a descriptive quantitative research (Booth \& Gerard, 2011; Morton et al., 2016). The purposive sampling was used for selecting schools partner (Ames, Glenton, \& Lewin, 2019; Etikan, 2016). The partcipants were three Adiwiyata Schools which are State Elementary School of 7 Sintang (Sekolah Dasar Negeri /SDN 7 Sintang), State Junior High School Sintang (Sekolah Madrasah Tsanawiah Negeri/MTsN Sintang), and State Junior High 
School of 3 Sungai Tebelian (Sekolah Menengah Pertama Negeri/SMPN 3 Sungai Tebelian). The main purpose of selecting these three schools are relies on variation in its level of Adiwiyata and its location. SDN 7 Sintang awarded as Adiwiyata school in national level is located in center city of Sintang. MTsN Sintang awarded as Adiwiyata school in district level is located in center city of Sintang. SMPN 3 Sungai Tebelian awarded as Adiwiyata school at province level is located on the edge of Sintang near airport of Sintang (Tebelian Airport). The assesmnet of Adiwiyata school in Sintang will give the information about riil condition of Adiwiyata program. This data will be used as a foundation to build the framework of Adiwiyata school program based on Sintang localities.

The data was gathered through questionnaire, in-depth interview and field observation, primarly used checklist for data confirmation (Jamal et al., 2013; Rusby, Crowley, Sprague, \& Biglan, 2011). The questionnaire was developed from Adiwiyata school assessment criteria (Ministry of Environment's Regulation number 5, 2013). Total of 11 informants ( 3 informants from SDN 7 Sintang, 3 informants from SMPN 3 Sungai Tebeian and 5 informants from MTsN Sintang) was involved in this research. The participants are conducted based on the illumination aspects. They come from different background but share similar expertise of Adiwiyata school management. This research informants are school stakeholders namely Principal, vice principal, teaching staff (teacher), administration staff, and other informants related to the field of the research.

The data from questionnaire was calculated and analyzed based on the guidance from Ministry of Environment's Regulation number 5, 2013. The scores taken from Adiwiyata school assessment then compared to Adiwiyata school category, as swohn in Table 1. The results from in-depth interview and field observation are used to confirm the questionnaire data (Jamal et al., 2013). Furthermore, the results from school environment assessment in all partner schools are used as a background in Strengths, Weaknesses, Opportunities and Threats (SWOT) analysis to conclude the development strategies of Adiwiyata school in Sintang district (Setiawan, 2017).

Table 1. Assessment category of Adiwiyata school

\begin{tabular}{|c|c|c|c|}
\hline No & Score range & Categorized & Note \\
\hline 1 & $<56$ & Not Adiwiyata school & all Adiwiyata components need more upgrade \\
\hline 2 & $56 \leq x<64$ & Adiwiyata school at District Level & $\begin{array}{l}\text { The school will be awarded as Adiwiyata School at Province } \\
\text { Level }\end{array}$ \\
\hline 3 & $64 \leq x<72$ & Adiwiyata school at Province Level & $\begin{array}{l}\text { The school will be awarded as Adiwiyata School at National } \\
\text { Level }\end{array}$ \\
\hline 4 & $72 \leq x \leq 80$ & $\begin{array}{l}\text { Adiwiyata school at National } \\
\text { School }\end{array}$ & $\begin{array}{l}\text { If the school can make ten }(10) \text { foster schools, It will be an } \\
\text { independent Adiwiyata school }{ }^{\star} \text { (The latest amendment of the } \\
\text { regulation declared that three (3) foster schools are enough to } \\
\text { be awarded as an independent Adiwiyata school) })^{\star *}\end{array}$ \\
\hline 5 & $\begin{array}{l}72 \leq x \leq 80 \text { Plus } \\
10 \text { foster schools* }\end{array}$ & Independent Adiwiyata school & $\begin{array}{l}\text { Verified by National Adiwiyata team under Ministry of } \\
\text { Environment and Forestry }\end{array}$ \\
\hline
\end{tabular}

Source: (Ministry of Environment's Regulation number 5, 2013)

Note: * Based on Ministry of Environment's regulation No 5, 2013

${ }^{* *}$ Based on Pers Comm. with Adiwiyata Program at Environmental Agency of Sintang District as PIC, 2019 (the regulation will be announced next year)

\section{RESULTS AND DISCUSSION}

\section{Adiwiyata school assessment}

The assessment toward schools categorized as Adiwiyata were derived from questionnaires by the school stakeholders itself (self-assessment) and observation checklist by the reseachers. Self-assessment done by stakeholders was constructed to gather the meaning in terms of pro-environmental behavior. The results of Adiwiyata schools assessment in Sintang District can be seen in Table 2.

The number of respondents were unequal depend on the depth of information represented by the school. The participants were respondents who were chosen based on the consideration of illumination aspects. There are three (3) partcipants SDN 7 sintang involved in the research. They are vice principal of academic affairs, who is also a Chief of Adiwiyata team along together with two other teaching staffs. Three partipcipants as well are from SMPN 3 Sungai Tebelian. They are also on the role of Principal, Vice principal on academic affairs, and administration staff. Otherwise, there are five partcipants drawn from MTsN Sintang; Principal (in-depth interview given only), Vice principal on academic affairs, Vice principal on student affairs, administration staff, and Chief of Adiwiyata team. 
Table 2. The results of Adiwiyata schools assessment in Sintang District

\begin{tabular}{|c|c|c|c|c|c|c|c|c|}
\hline \multicolumn{3}{|c|}{ SDN 7 Sintang } & \multicolumn{3}{|c|}{ SMPN 3 Sungai Tebelian } & \multicolumn{3}{|c|}{ MTsN Sintang } \\
\hline \multirow{2}{*}{ Score } & \multicolumn{2}{|c|}{ Category } & \multirow{2}{*}{ Score } & \multicolumn{2}{|c|}{ Category } & \multirow{2}{*}{ Score } & \multicolumn{2}{|c|}{ Category } \\
\hline & Current & Assesment & & Current & Assesment & & Current & Assesment \\
\hline 73.15* & $\begin{array}{l}\text { Adiwiyata } \\
\text { school at } \\
\text { National } \\
\text { Level }\end{array}$ & $\begin{array}{l}\text { awarded as } \\
\text { Independent } \\
\text { Adiwiyata } \\
\text { school }\end{array}$ & 70.40 & $\begin{array}{l}\text { Adiwiyata } \\
\text { school at } \\
\text { Province } \\
\text { Level }\end{array}$ & $\begin{array}{l}\text { Adiwiyata } \\
\text { school at } \\
\text { Province level }\end{array}$ & 68.13 & $\begin{array}{l}\text { Adiwiyata } \\
\text { school at } \\
\text { District } \\
\text { Level }\end{array}$ & $\begin{array}{l}\text { Progresse to } \\
\text { be awarded } \\
\text { as Adiwiyata } \\
\text { school at } \\
\text { Province level }\end{array}$ \\
\hline
\end{tabular}

Based on the result, in this study, all the Adiwiyata schools have implemented the program very well. From Table 2, it may be seen that the assessment score is above the standard. SDN 7 Sintang with scores of 73.15 can be awarded as Adiwiyata school on national level. The presence of three foster schools of Adiwiyata, SDN 7 Sintang tended to be categorized as Independent Adiwiyata school. SDN 7 Sintang is the pioneer of Adiwiyata school program in Sintang Regency. The internal system is well formed. This factor make the Adiwiyata program can be implemented well. SMPN 3 Sungai Tebelian is categorized as Adiwiyata school on Province level with the score of 70.40. The speciality of SMPN 3 Sungai Tebelian is they have the large land and have good external collaboration with other organisations. MTsN Sintang progressed to be Adiwiyata school on Province level considered to be score of 68.13. This school has a program which similar to Adiwiyata school which is Sekolah Sehat (Healthy school program). This program supports the school to fulfill the criteria in Adiwiyata school program. SDN 7 Sintang has the highest score than other, 73.15 score. This school has fulfilled almost of all component in Adiwiyata school. The desirable outcome constructed is compatible with those of another in achievement came from the collaboration by all citizens of school (Hunt, Barrios, Telljohann, \& Mazyck, 2015; Nurwidodo et al., 2019). The role of School principal and his team are very important to encourage and manage the team work in SDN 7 Sintang. In School management, the Principal works as the manager of school as well as the planner, the organizer, the leader, and the controller (Pradini, Sudjanto, \& Nurjannah, 2019; Rizki, Azmi, Sobri, Nurabadi, \& Malang, 2018).

SDN 7 Sintang is located in the center of Sintang city. It's surrounded by some other schools namely State kindergarten of 2 Sintang (TK Negeri 2 Sintang), State Junior High School of 2 Sintang (SMPN 2 Sintang) and State Senior High School of 2 Sintang (SMAN 2 Sintang). The presence of these schools created the environmental education and greater competition in maintaining of their (environmentally friendly school program) clean and comfortable school environment. These factors structutred to be key success in developing an Adiwiyata school (DiMenichi \& Tricomi, 2015; Hunt et al., 2015).

SMPN 3 Sungai Tebelian is located on Sungai Tebelian sub-district, about $17 \mathrm{Km}$ from Sintang city center. The location is near of Tebelian Airport of Sintang. The development of city is in this location. The distance between the school and the city center tended to undermine the encouragement of Environmental Agencies in Sintang. The key success in encouraging the school to be Adiwiyata School should be fully supported by all the citizen members of school and partcularly assisted by the Principal team. This school was working jointly with the village government of Sungai Ukoi to build the access road to the school. The collaboration only can be constructed with good leadership of school principal team (Hunt et al., 2015). For further development of Adiwiyata program, a school need to involve relevant third parties in terms of human resources (Keselman, Levin, Kramer, Matzkin, \& Dutcher, 2011; Nurwidodo et al., 2019; Sloot et al., 2018).

MTsN Sintang is located in Sintang city center near by Baning Stadium of Sintang. the supervision in sustaining Adiwiyata program in this school was obtained well. The Adiwiyata school's score on district level reached out a number of Adiwiyata school on province level, as shown in (Table 3). Good management followed by all citizens of school attempt to reach the success, Educational leaders, have to think of giving direction to the followers, society and even to the world (Luqman, Farhan, Shahzad, \& Shaheen, 2012). The role of the principal's team is important in maintaining a good school environment to get their influence in other schools (Al-safran, Brown, \& Wiseman, 2000; Balyer, Karatas, \& Alci, 2015; Bredeson \& Johansson, 2000; Mejia, 2016; Mestry, 2017), and also other external support to preserve a good school environment (Darling-Hammond, Flook, Cook-Harvey, Barron, \& Osher, 2019; DiMenichi \& Tricomi, 2015; Serdyukov, 2018). 
Based on the field observation, overall, the Adiwiyata schools environment has shown good quality of existing school environmental. SDN 7 Sintang has much kind of ornamental plants which plants in front of school. They also used vertical garden to address the lack of land, as shown in (Figure 1A). SMPN 3 Sungai Tebelian has many shade plants in school environment which provide fresh air and good condition for learning. They also have mutual collaboration with surrounding neighbor to maintenance the clean environment, as shown in (Figure 1B). In MTsN Sintang, they have some Palm trees which used as shade and ornamental plants. They also plants other ornamental plants in school garden but not growth well because existence of infertile soil called Kerangas soil, as shown in (Figure 1C).

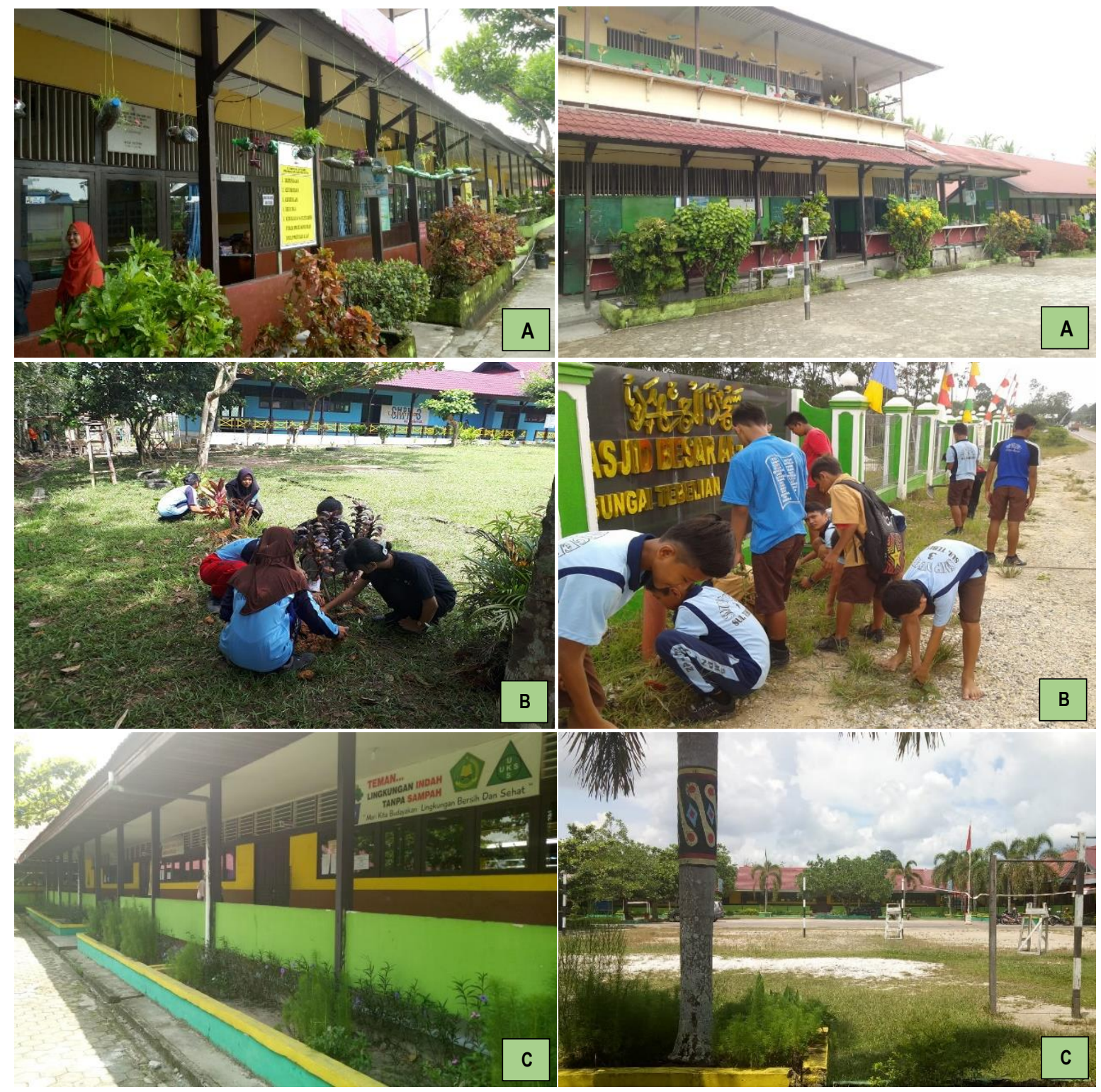

Figure 1. School environment and school activities in Adiwiyata school of Sintang district A) SDN 7 Sintang, B) SMPN 3 Sungai Tebelian, C) MTSN Sintang

Many kinds of plants are planted in the garden, green house, vertical garden and other area. However, there is still lack of diversity. The rich of biodiversity in Sintang district is not optimally used. In constructive to this matter, the biodiversity of local fruit plants namely Rambutan (Nephelium lappaceum), Mangga hutan (Genus of Mangifera), Belimbing Darah (Baccaurea angulata), Durian hutan (Genus of Durio) are some examples of local potentials which can be planted in school environment. In doing so, the jointly work with Department of agriculture can be initiated to provide the local fruit plant seedling. The local fruit planting will lead to a sense of belonging from all citizens in the school towards their environments (Ashktorab, 
Hasanvand, Seyedfatemi, Salmani, \& Vahide, 2017; Kitchen, Williams, \& Gallina, 2015). The home garden symbolizes the place, identity, and sense of belonging of people. Subjective elements of a home garden if realized will influence people's behavior in daily life (Belon, Nieuwendyk, Vallianatos, \& Nykiforuk, 2016; Cheang, So, Zhan, \& Tsoi, 2017; Ghazali, 2013; Samuelsson et al., 2018; Stoltz \& Schaffer, 2018; Ten Brink et al., 2016).

\section{The analysis of strategy-formulation framework for development of local Adiwiyata school program}

Based on the results of in-depth interview and field observation, in general, some of the specific components of Adiwiyata School in Sintang district include: (1) the schools have an unwritten rule which state that if the plants were cut off, it has to be replaced with the same or better plants; (2) the disposable plastic products are forbidden to use in school area by the canteen vendors; (3) the students have to clean their own environment every day before start the lessons; (4) all citizen of school are involved to build and manage school garden, the pool, green house, medicinal plant garden; (5) all citizen of school make some handicrafts from plastic waste; and (6) the district government through Environmental Agency of Sintang District conducted some regular supervisions toward Adiwiyata schools.

The specific components in this formulation framework can be used as a basic foundamental in developing Local Adiwiyata School Program. The differences occur because of different culture and tradition in each location (Altweck \& Marshall, 2015; Caddafie et al., 2017; Kitchen et al., 2015). People's perception about waste are vary depend on how it benefits them. People who live near the Waste Management Facility (WMF) will have different visions to people who live in high class settlements. The waste is one of income sources to people who live near the WMF. All citizen of the school will process the waste into useful things which has economic values such as organic fertilizer, plastic handicrafts and so on. The different visions about waste also appear in the society who lives in the city and the village. Urban people usually use the household waste namely plastic bottles, cans, clothing and so forth. Meanwhile, villagers usually deal with the organic waste namely leaf, branches, animal waste, and so on. All These different perceptions about waste will lead to particular paradigm in order to formulate specific development strategies. According to Ferronato \& Torretta (2019) environmental contamination due to solid waste mismanagement is a global issue, measuring the comprehensive impact and planning of solid waste collection with a good treatment system, will increase awareness of sustainable waste management.

Based on field observation, Sintang district has some local unique to support the development of Adiwiyata school program. It include: (1) the rich of fruit plant diversity in Sintang district which can be cultivated in school environment; (2) many universities support the development of local human resources in anticipating global environmental issues which growth recently; and (3) people in Sintang still preserve culture and tradition based on their sense of belonging to the environment.

This local unique can be used as a foundation of formulating sustainable Adiwiyata school. The further analysis of specific strategies in developing Adiwiyata school or SWOT analysis in Sintang district can be seen in Table 3. The local uniqueness from Sintang regency is a key factors to develop the local Adiwiyata school program. Based on S-O strategies in Table 3, the local government and also school board can develop the regulation to plants the local fruit plants as shading, ornamental plants, and medicinal plants in school environment. The sustainable district program (Program Kabupaten Sintang Lestari) is also supporting factor to develop local Adiwiyata school program. Local government through Environmental Agency is open to collaborate to school and provide the knowledge and guidance to improve the quality of school environment. Local tradition of helping each other is good tradition to implement in school and surrounding neighbor. The utilization of district specific localities is also implemented in other area like in West Sumatra which used the local wisdom of Minangkabau to improve the identity of Adiwiyata school (Astuti, 2017).

Based on the results of school environment assessment, in-depth interview and SWOT analysis (Table 3), some specific strategies can be formulated to develop the local Adiwiyata school in Sintang district: (1) Improving students' sense of belonging on students toward the environment by doing planting, preserving, and harvesting of local plants such as local vegetables, local fruit plants, local shade plants and so on. (2) Utilizing a culture of mutual cooperation arround community to preserve the school environment. It can be started by cleaning up the Village facilities such as Village office, village drainage, and so on. (3) Formulating the working group of adjacent school in term of sharing knowledge and skill about managing the Adiwiyata school. (4) Building a formal-open access website/online sharing media/social media/campaign media (should be initiated by Environmental agency of Sintang district) to accommodate the publication of pro-environmental activities from all Adiwiyata school in Sintang district. 
Table 3. SWOT analysis used in formulating strategies for development of local Adiwiyata school program in Sintang District

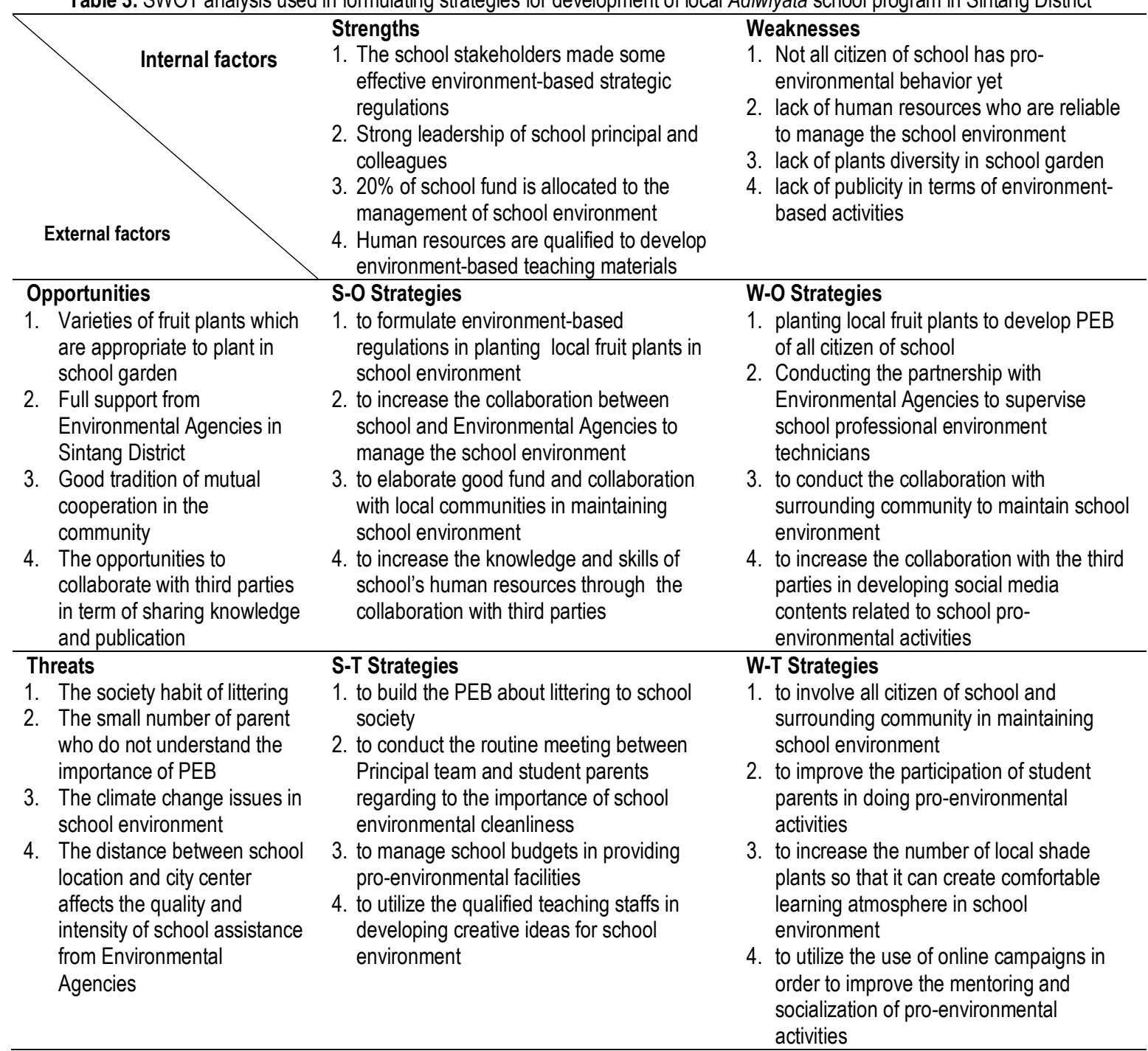

Building the collaboration networking with universities in Sintang district which has knowledge and skills about developing and preserving the environment. Ensuring quality in creating the environment is a shared responsibility, by developing a cultural network of social responsibility (Pero, Moretto, Bottani, \& Bigliardi, 2017). Effective collaborative teams exhibit important outcomes, far beyond what could be accomplished by individualsworking independently (Cheruvelil et al., 2014).

\section{CONCLUSION}

The results from Adiwiyata school assessment indicates that the school is implemented the program very well. Its known from the score of asessment 73.15 in SDN 7 Sintang (plus three foster schools they can be categorized as Independent Adiwiyata school), 70.40 in SMPN 3 Sungai Tebelian which categorized as Adiwiyata school on Province level, and 68.13 in MTsN Sintang which progressed to be Adiwiyata school on Province level. Every Adiwiyata school in Sintang district has their specialty, in SDN 7 Sintang they are surrounding by three schools in different level which make a good competition to maintain their environment clean. SMPN 3 Sintang is used their collaboration with local community to build the facility around the school. MTSN Sintang has a good internal leadership and support from surrounding environment to clean their school. Based on SWOT analysis, the specific strategies on developing Adiwiyata school in Sintang district include utilizing of local uniqness such as planting of local plants, developing of local culture and tradition on mutual collaboration with surrounding community, and increasing partnership with Environmental agencies and third parties in developing the professional human resources in maintaining school environment. 


\section{ACKNOWLEDGMENT}

Sincerely thanks to DRPM (Direktorat Riset dan Pengabdian Masyarakat or Directorate of Research and Community Engagement) of Ministry of Research and Technology of the Republic of Indonesia for funding this research. We also thanks to Environmental Agencies in Sintang district for the data and research recommendations. Many thanks also goes to our school partners' stakeholder, SDN 7 Sintang, SMPN 3 Sungai Tebelian and MTsN Sintang. Our special thanks go to Mr Lensi Thomas and Mr Stevanus for their help in conducting the research.

\section{REFERENCES}

Al-safran, E., Brown, D., \& Wiseman, A. (2000). The effect of principal's leadership style on school environment and outcome. Research in Higher Education Journal The, 22, 1-19. Retrieved from https:/l www.aabri.com/manuscripts/131666.pdf

Altweck, L., \& Marshall, T. C. (2015). When you have lived in a different culture, does returning "home" not feel like home? predictors of psychological readjustment to the heritage culture. PLOS ONE, 10(5), 117. doi: https://doi.org/10.1371/journal.pone.0124393

Ames, H., Glenton, C., \& Lewin, S. (2019). Purposive sampling in a qualitative evidence synthesis: A worked example from a synthesis on parental perceptions of vaccination communication. BMC Medical Research Methodology, 19(1), 1-9. doi: https://doi.org/10.1186/s12874-019-0665-4

Ashktorab, T., Hasanvand, S., Seyedfatemi, N., Salmani, N., \& Vahide, S. (2017). Factors affecting the belongingness sense of undergraduate nursing students towards clinical setting: A qualitative study. Tabriz University of Medical Sciences, 6(3), 221-235. doi: https://doi.org/10.15171/jcs.2017.022

Astuti, D. (2017). Revitalisasi kearifan lokal Minangkabau dalam pelaksanaan program sekolah adiwiyata di Sumatera Barat. Jurnal Pembangunan Nagari, 2(2), 217-229. Retrieved from http://ejournal.sumbar prov.go.id/index.php/jpn/article/view/38

Balyer, A., Karatas, H., \& Alci, B. (2015). School principals' roles in establishing collaborative professional learning communities at schools. Procedia - Social and Behavioral Sciences, 197(February), 13401347. doi: https://doi.org/10.1016/j.sbspro.2015.07.387

Belon, A. P., Nieuwendyk, L. M., Vallianatos, H., \& Nykiforuk, C. I. J. (2016). Perceived community environmental influences on eating behaviors: A Photovoice analysis. Social Science and Medicine, 171, 18-29. doi: https://doi.org/10.1016/j.socscimed.2016.11.004

Booth, M. Z., \& Gerard, J. M. (2011). Self-esteem and academic achievement: A comparative study of adolescent students in England and the United States. Compare, 41(5), 629-648. doi: https://doi.org/10. 1080/03057925.2011.566688

Bredeson, P. V., \& Johansson, O. (2000). The school principal's role in teacher professional development. Journal of In-Service Education, 26(2), 385-401. doi: https://doi.org/10.1080/13674580000200114

Bronfman, N. C., Cisternas, P. C., López-Vázquez, E., De la Maza, C., \& Oyanedel, J. C. (2015). Understanding attitudes and pro-environmental behaviors in a Chilean community. Sustainability, $7(10)$, 14133-14152. doi: https://doi.org/10.3390/su71014133

Caddafie, S. U., Kariada, N., Martuti, T., Rudyatmi, E., \& Article, I. (2017). The impact of adiwiyata program on environmental caring character. Journal of Biology Education, 6(3), 350-356. Retrieved from https:/l journal.unnes.ac.id/sju/index.php/ujbe/article/view/21090

Cheang, C. C., So, W. M. W., Zhan, Y., \& Tsoi, K. H. (2017). Education for sustainability using a campus ecogarden as a learning environment. International Journal of Sustainability in Higher Education, 18(2), 242-262. doi: https://doi.org/10.1108//JSHE-10-2015-0174

Cheruvelil, K. S., Soranno, P. A., Weathers, K. C., Hanson, P. C., Goring, S. J., Filstrup, C. T., \& Read, E. K. (2014). Creating and maintaining high-performing collaborative research teams: The importance of diversity and interpersonal skills. Frontiers in Ecology and the Environment, 12(1), 31-38. doi: https:// doi.org/10.1890/130001

Darling-Hammond, L., Flook, L., Cook-Harvey, C., Barron, B., \& Osher, D. (2019). Implications for educational practice of the science of learning and development. Applied Developmental Science, O(0), 1-44. doi: https://doi.org/10.1080/10888691.2018.1537791

De Dominicis, S., Schultz, P. W., \& Bonaiuto, M. (2017). Protecting the environment for self-interested reasons: Altruism is not the only pathway to sustainability. Frontiers in Psychology, 8(JUN), 1-13. doi: 
https://doi.org/10.3389/fpsyg.2017.01065

DiMenichi, B. C., \& Tricomi, E. (2015). The power of competition: Effects of social motivation on attention, sustained physical effort, and learning. Frontiers in Psychology, 6(September), 1-13. doi: https://doi.org/ 10.3389/fpsyg.2015.01282

Estrada, M., Schultz, P. W., Silva-Send, N., \& Boudrias, M. A. (2017). The role of social influences on proenvironment pehaviors in the San Diego Region. Journal of Urban Health, 94(2), 170-179. doi: https:// doi.org/10.1007/s11524-017-0139-0

Etikan, I. (2016). Comparison of convenience sampling and purposive sampling. American Journal of Theoretical and Applied Statistics, 5(1), 1-4. doi: https://doi.org/10.11648/j.ajtas.20160501.11

Ferronato, N., \& Torretta, V. (2019). Waste mismanagement in developing countries: A review of global issues. International Journal of Environmental Research and Public Health, 16(6), 1-28. doi: https://doi. org/10.3390/ijerph16061060

Ghazali, S. (2013). House garden as a symbol of place, identity and sense of belonging for low-cost flat residents in urbanizing Malaysia. International Journal of Social Science and Humanity, 3(2), 171-175. doi: https://doi.org/10.7763/ijssh.2013.v3.221

Goldstein, S., \& Brooks, R. B. (2013). Creating a positive schools climate: A Foundation for Resilience. In S. Goldstein \& R. B. Brooks (Eds.), Handbook of Resilience in Children: Second Edition (pp. 1-527). doi: https://doi.org/10.1007/978-1-4614-3661-4

Horta, R. L., Andersen, C. S., Pinto, R. O., Horta, B. L., Campos, M. O., Andreazzi, M. A. R. de, \& Malta, D. C. (2017). Health promotion in school environment in Brazil. Revista de Saude Publica, 51(27), 1-12. doi: https://doi.org/10.1590/S1518-8787.2017051006709

Hunt, P., Barrios, L., Telljohann, S. K., \& Mazyck, D. (2015). A whole school approach: Collaborative development of school health policies, processes, and practices. Journal of School Health, 85(11), 802809. doi: https://doi.org/10.1111/josh.12305

Husin, A., \& Saleh, A. (2019). Opportunities for the school system to instill environmental values. Journal of Environmental Protection, 10, 1649-1656. doi: https://doi.org/10.4236/jep.2019.1012098

Kementerian Lingkungan Hidup Republik Indonesia. (2013). Peraturan menteri lingkungan hidup Republik Indonesia nomor 05 tahun 2013 tentang pedoman pelaksanaan program adiwiyata. Retrieved from https://bulelengkab.go.id/assets/instansikab/82/bankdata/peraturan-menteri-nomor-5-tahun-2013-tentan g-pedoman-adiwiyata-16.pdf.

Jamal, F., Fletcher, A., Harden, A., Wells, H., Thomas, J., \& Bonell, C. (2013). The school environment and student health: A systematic review and meta-ethnography of qualitative research. BMC Public Health, 13(1), 1-11. doi: https://doi.org/10.1186/1471-2458-13-798

Keselman, A., Levin, D. M., Kramer, J. F., Matzkin, K., \& Dutcher, G. (2011). Educating young people about environmental health for informed social action. Umwelt Und Gesundheit Online, 4, 1-8. Retrieved from Retrieved from https://www.ncbi.nlm.nih.gov/pmc/articles/PMC3875179/

Kitchen, P., Williams, A. M., \& Gallina, M. (2015). Sense of belonging to local community in small-to-medium sized Canadian urban areas: A comparison of immigrant and Canadian-born residents. BMC Psychology, 3(1), 1-17. doi: https://doi.org/10.1186/S40359-015-0085-0

Luqman, R. A., Farhan, H. M., Shahzad, F., \& Shaheen, S. (2012). 21st Century challenges of educational leaders, way out and need of reflective practice. International Journal of Learning and Development, 2(1). doi: https://doi.org/10.5296/ijld.v2i1.1238

Mejia, M. T. (2016). The role of principals in creating a healthy environment for teachers and students. In Capstone Projects and Master's Theses (No. 36). Retrieved from https://digitalcommons.csumb.edu/cgi/ viewcontent.cgi?article $=1035 \&$ context=caps_thes_all

Mestry, R. (2017). Principals' perspectives and experiences of their instructional leadership functions to enhance learner achievement in public schools. Journal of Education, (69), 257-280. Retrieved from http://www.scielo.org.za/pdf/jed/n69/12.pdf

Morton, K. L., Atkin, A. J., Corder, K., Suhrcke, M., \& van Sluijs, E. M. F. (2016). The school environment and adolescent physical activity and sedentary behaviour: A mixed-studies systematic review. Obesity Reviews, 17(2), 142-158. doi: https://doi.org/10.1111/obr.12352

Nurwidodo, N., Al Muhdar, M. H. I., Rohman, F., Iriani, D., Herlina, H., \& Fausan, M. M. (2019). Building proenvironmental behavior among school community of Adiwiyata green school. Jurnal Pendidikan Biologi Indonesia, 5(1), 23-32. doi: https://doi.org/10.22219/jpbi.v5i1.7233

Pero, M., Moretto, A., Bottani, E., \& Bigliardi, B. (2017). Environmental collaboration for sustainability in the 
construction industry: An exploratory study in Italy. Sustainability (Switzerland), 9(1), 1-25. doi: https:// doi.org/10.3390/su9010125

Pradini, I. K., Sudjanto, B., \& Nurjannah, N. (2019). Implementasi program sekolah adiwiyata dalam peningkatan mutu pendidikan di SDN Tanah Tinggi 3 Kota Tangerang. Jurnal Green Growth Dan Manajemen Lingkungan, 7(2), 122-132. doi: https://doi.org/10.21009/jgg.072.03

Rachman, S. P. D., \& Maryani, E. (2018). Teachers' and students' green behaviour of Adiwiyata targeted school. IOP Conference Series: Earth and Environmental Science, 145(1), 012042. doi: https://doi.org/ 10.1088/1755-1315/145/1/012042

Rizki, N., Azmi, L., Sobri, A. Y., Nurabadi, A., \& Malang, U. N. (2018). Kepemimpinan ekologis kepala sekolah dalam pembentukan sekolah berbudaya lingkungan. JAMP: Jurnal Administrasi Dan Manajemen Pendidikan, 1(3), 327-336. Retrieved from Retrieved from http://journal2.um.ac.id/index.php/jamp/arti cle/download/4877/2642

Rusby, J. C., Crowley, R., Sprague, J., \& Biglan, A. (2011). Observation of the middle school environment: The context for student behavior beyond the classroom. Psychology in the Schools, 48(4), 400-415. doi: https://doi.org/10.1002/pits.20562

Samuelsson, K., Giusti, M., Peterson, G. D., Legeby, A., Brandt, S. A., \& Barthel, S. (2018). Impact of environment on people's everyday experiences in Stockholm. Landscape and Urban Planning, 171(July 2017), 7-17. doi: https://doi.org/10.1016/j.landurbplan.2017.11.009

Serdyukov, P. (2018). Innovation in education: What works, what doesn't, and what to do about it? Journal of Research in Innovative Teaching \& Learning, 10(1), 4-33. doi: https://doi.org/10.1108/rit-10-2016-0007

Setiawan, H. (2017). Nepenthes as tourism flagship species: The conservation strategies in Dayak Seberuang settlements area. Journal of Indonesian Tourism and Development Studies, 5(2), 113-120. doi: https://doi.org/10.21776/ub.jitode.2017.005.02.07

Sloot, D., Kutlaca, M., Medugorac, V., \& Carman, P. (2018). Recycling alone or protesting together? values as a basis for pro-environmental social change actions. Frontiers in Psychology, 9(JUL), 1-10. doi: https:// doi.org/10.3389/fpsyg.2018.01229

Stoltz, J., \& Schaffer, C. (2018). Salutogenic affordances and sustainability: Multiple benefits with edible forest gardens in urban green spaces. Frontiers in Psychology, 9(DEC). doi: https://doi.org/10.3389/fpsyg.20 18.02344

Ten Brink, P., Mutafoglu, K., Schweitzer, J.-P., Kettunen, M., Twigger-Ross, C., Baker, J., ... Ojala, A. (2016). The health and social benefits of nature and biodiversity protection: A report for the European Commission (ENV.B.3/ETU/2014/0039). Retrieved from https://ec.europa.eu/environment/nature/bio diversity/intro/docs/Health and Social Benefits of Nature - Final Report Main sent.pdf

Trihantoyo, S., \& Rahma, A. (2018). Green school program management in fostering students' character. Advances in Social Science, Education and Humanities Research (ASSEHR), 108(SoSHEC 2017), 4548. doi: https://doi.org/10.2991/soshec-17.2018.9

Warju, W., Ariyanto, S. R., \& Muzaki, L. (2018). Developing integrated curriculum with environmental education at vocational high school. Advances in Social Science, Education and Humanities Research (ASSEHR), 201(Aptekindo), 21-27. doi: https://doi.org/10.2991/aptekindo-18.2018.5 